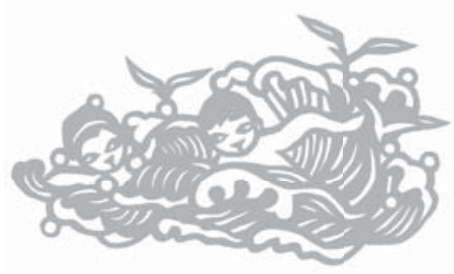

\title{
NOWE KOMPENDIUM WIEDZY O CHINACH
}

Wiesław Olszewski, Chiny - Zarys kultury, Wydawnictwo Naukowe UAM, Poznań 2003, 375 str.

Jest to, bez wątpienia, książka ważna i bardzo użyteczna. Wiesław Olszewski, znany badacz dziejów Wietnamu, przygotował tym razem swoiste popularne kompendium kultury chińskiej, interpretując to pojęcie dość szeroko, w duchu antropologicznym. To obszerne i starannie wydane dzieło wzbogacają liczne ilustracje, głównie barwne. Rozdział I zatytułowany został Chiny - ich przeszłość i tradycje. Zaczyna się on przedstawieniem kraju i jego mieszkańców (obszaru, podziału administracyjnego, głównych regionów geograficznych i składu etnicznego ludności - z mapą rozmieszczenia ważniejszych narodowości). Czytelnik znajdzie tu sztandary państwa chińskiego od epoki cesarskiej do dziś, fotografie niektórych zwierząt, ludów i miejsc, a także rysunki dawnych podróżników, co ogromnie wzbogaca i ubarwia dzieło. Podpisy pod nimi bywają nieraz rozbudowane do „,mini-szkicu informacyjnego". Zgodnie z nowymi tendencjami do tekstu włączone zostały także, wyodrębnione drukiem, krótkie ,szkice tematyczne”, jak np. opisy pantery śnieżnej, wielbłąda dwugarbnego i słonia, Rzeki Żółtej, Placu Tiananmen, Wielkiego Kanału i rozwoju budowy kanałów, słonego Jeziora Łob-Nor, jurty, specyfiki pojmowania jednostki w Chinach, Tybetu oraz jego statusu przez wieki, ludu Yi, muzułmanów w Xinjiangu, ludów stepowych przez wieki najeżdżających Chiny, muzułmanów Huiów, państwowości mongolskiej, południowych ludów Zhuangów i Wa, bambusa, ryżu i opium. Wartość ich powiększają dodawane czasem zalecenia literatury przedmiotu. Już choćby to wyliczenie „szkiców tematycznych”, z konieczności skrótowe, pokazuje, jak bardzo wzbogacają one podstawowy opis. Łącznie stanowią one chyba sporo ponad połowę objętości pracy.

Kolejne paragrafy tego rozdziału poświęcone są językowi i pismu chińskiemu; dorobkowi naukowo-technicznemu Chin; tradycyjnemu państwu i jego strukturom 
polityczno-społecznym; wierzeniom, kultom i myśli filozoficznej; kalendarzowi, dorobkowi chińskiej astronomii i astrologii; świętom i „festiwalom”, medycynie chińskiej i jej farmakopei; sportom i rozrywkom; kuchni (omawia się tam także niektóre przyprawy oraz rośliny uprawne); i na końcu - herbacie. Jest to rozdział najobszerniejszy stanowiący połowę książki (str. 9-188). Rozdział II poświęcony został historii literatury i sztuk rozmaitych, w tym muzyki, sztuk scenicznych, kaligrafii, malarstwu, ceramice i porcelanie, brązom, lace, zdobnym jedwabiom i strojom. (str. 191-273). Rozdział III dotyczy zabytków architektury (dawnego Pekinu i jego zabytków, parków i ogrodów, nekropolii cesarskich, świątyń i pagód, jak też Wielkiego Muru, str. 277-370). Książkę uzupełnia lista dynastii chińskich, i lista cesarzy ostatnich dwu dynastii, Ming (1368-1644) i Qing (1644-1912).

Dużym walorem tej pracy jest historyczne podejście Autora. Każda niemal kwestia została ukazana w perspektywie tysiącleci, czy stuleci, co w kraju o starożytnej cywilizacji, takim jak Chiny, jest szczególnie potrzebne. Ponadto ukazany też został pluralizm Chin, ogromne zróżnicowanie tego kraju we wszystkich niemal aspektach, o czym nieraz zapominają dziennikarze piszący zwykle z perspektywy Pekinu, czy Szanghaju. Autor starał się też, i to z dobrymi rezultatami, przedstawiać w sposób obiektywny i uczciwy kwestie budzące rozmaite kontrowersje. Widać także znajomość kraju, a nawet całego regionu, i ludzi z autopsji, a nie tylko z książek. Niewątpliwie ma też Autor dar zajmującego opowiadania.

Jest oczywiście trudno przygotować taką encyklopedyczną w istocie pracę, a opisy muszą być - siłą rzeczy - skrótowe, zaś dobór tematyczny niemal zawsze budzić będzie wątpliwości, gdyż każdy specjalista ma swoje predylekcje. Książka, jak już stwierdzono powyżej, jest niewątpliwie bardzo potrzebna i bardzo pożyteczna. Została też pięknie wydana, napisana po większej części jasnym językiem, i powinna znaleźć się na półce każdej osoby interesującej się Chinami, gdyż stanowi użyteczne kompendium wiedzy o tym kraju-kontynencie. $Z$ tym większym zatem żalem trzeba odnotować pewne jej słabości.

Przede wszystkim brakuje w niej szczegółowego spisu wspomnianych powyżej „szkiców tematycznych”, indeksu, czy spisu ilustracji (ważnego tym bardziej, iż towarzyszy im często rozbudowany i dość szczegółowy opis). Cóż z tego, że pamiętamy, iż gdzieś widzieliśmy opis bambusa, czy jurty, jeśli musimy ich poszukiwać kartkując całą książkę! To zmniejsza ogromnie użyteczność pracy i bardzo utrudnia szybkie korzystanie z niej, niwecząc w dużym stopniu wysiłek Autora włożony w przygotowanie tych rozmaitych opisów. Wspomnieć jeszcze trzeba, że ich układ tematyczny wcale nie ułatwia odnajdywania ich. Np. niektóre zwierzęta, jak wspomniano, są opisane w rozdziale I, ale panda - w paragrafie poświęconym zabytkom Pekinu! Nie jest też łatwo odgadnąć, dlaczego jedne opisy przygotowano, innych zaś brak, i jakie kryteria przyjęto dzieląc je na rozmaite kategorie. Owe „szkice tematyczne” nie mają też tytułów, czy wyodrębnionego jakoś graficznie „tematu”, co narzucało by Autorowi pewną dyscyplinę opisu. Niestety odbi- 
ja się to nieraz na treści, ujmowanej dość chaotycznie. Niekiedy trudno by nawet obecnemu opisowi dać jakiś precyzyjny tytuł, gdyż w jednym fragmencie pisze się o różnych sprawach. Np. na str. 21 czytamy najpierw o geografii pustynnych obszarów na pograniczu Chin i Mongolii, potem o Czarnym Mieście z tego regionu, gdzie chronili się potomkowie obalonej w Chinach mongolskiej dynastii Yuan (1271-1368), a potem o zachowaniu swej tożsamości przez Mongołów, inaczej niż w przypadku innych zdobywców, którzy ulegli sinizacji. Kończy to hipoteza, iż prawdopodobnie odrzucenie kultury południowego sąsiada było przyczyną negatywnej oceny ich rządów przez Chińczyków. Zaprzeczają temu jednak dalsze wywody, gdzie mówi się o wyzysku chińskiego chłopstwa i opisuje się bunty ludowe, które doprowadzily do obalenia dynastii Yuan i ustanowienia chińskiej dynastii Ming (1368-1644). Przedstawia się społeczne przyczyny sukcesu powstania i ogłoszenia Nankinu stolicą. Kończy to informacja, iż mury jego liczyły 30 $\mathrm{km}$. Wspomina się jeszcze, że Pekin, jako Chanbałyk, był stolicą dynastii Yuan. Wszystko to ma łącznie objętość 30 wierszy, czyli trochę ponad pół strony i większość kapitalnych tematów przedstawiona została w jednym lub dwu zdaniach, które przy takim skrócie są nieraz wątpliwej wartości. Gdyby wybrano z tego kilka tematów, jak charakterystyka geograficzna północnego pogranicza, życie na stepach mongolskich, podbój Chin przez Mongołów, przyczyny upadku dynastii Yuan, proces ustanowienia dynastii Ming, stołeczność Nankinu i Pekinu, polityka obcych zdobywców a problem ich sinizacji, tradycje powstań ludowych i ustanawiania nowej dynastii, czy opis stołecznego Nankinu za Mingów, i poświęcono każdemu z wybranych tematów jeden uporządkowany szkic - czytelnik zdobyłby jakąś wiedzę przynajmniej o niektórych sprawach. Z obecnego opisu dowie się zaś niewiele. Tym bardziej, iż sporo tu nieścisłości i pojawia się nawet błąd: podaje się, że nazwa Ming znaczy „Wspaniała”, podczas gdy hieroglif ten znaczy przede wszystkim ,jaśniejąca”, „świecąca blaskiem”.

Na str. 49 znajdujemy inny tego typu opis. Zaczyna się on od problemu wynalazku i wyrobu żeliwa i stali w Chinach. Następnie Autor wymienia, co robiono tam z żelaza. Wymieniwszy mosty na łańcuchach żelaznych zaczyna opisywać typy mostów. Wspomniawszy wodę, przechodzi do jej technicznego wykorzystywania. Powraca znowu do miechów i żelaza, i tu okazuje się, że do ich poruszania wynaleziono nawet w VI w. maszynę parową, co przyczyniło się do rozwoju metalurgii. W opisie tym jeszcze kilkakroć porównuje się zdobycze metalurgiczne Chin i Zachodu. Znowu mamy tu kilka fascynujących i niezmiernie ważnych tematów, o których uzyskujemy tylko ułamki informacji chaotycznie splątanych ze sobą na zasadzie luźnych skojarzeń.

Ponadto sam dobór ilustracji i tych „opisów uzupełniających” sprawia wrażenie przypadkowości. Oczywiście taki swoisty „bigos informacyjny” ma swój urok, ale miejscami przekracza to granice rozsądku i niekorzystnie rzutuje na zarysowany obraz Chin. Weźmy jako przykład paragraf 1 z Rozdziału I: opis Chin. Ilustracje 
przedstawiające „krainy geograficzne” dotyczą głównie etnicznych peryferii: pustyni, jurty, wiejskich domów na palach mniejszości zamieszkujących dalekie południe, itd. Z Chin właściwych znajdziemy tam właściwie tylko przypadkowe pole ryżowe i fotografię Trzech Przełomów Yangzi. Nie znajdziemy tam fotografii z tak specyficznej krainy lessowej, gdzie znajdowała się kolebka cywilizacji chińskiej, wciąż tam występujących domostw - wydrążonych w zboczu lessowym, czy też tradycyjnych wsi chińskich. Nie ma też pejzażu chińskiego z Północy i Południa, równin i specyficznych gór stanowiących tak częsty motyw w malarstwie chińskim. Podobnie przedstawia się sprawa zwierząt. Pantera śnieżna jest niewątpliwie ciekawym zwierzęciem, lecz nawet dla Chińczyków nader „egzotycznym”, podobnie jak wielbłąd dwugarbny z pustyń i stepów, czy słonie z dalekiego południa. Trudno jednak, by nie dziwił w tej sytuacji brak zwierząt „typowo chińskich": tygrysa - zajmującego tak eksponowane miejsce w kulturze, podobnie jak żurawia, czy jeleni. Jeśli już autor zechciał pokazać kilka zwierząt z Chin - to chyba należało wybrać te charakterystyczne, czy odgrywające największą rolę w kulturze i symbolice. Może warto też było wymienić ważniejsze chińskie zwierzęta domowe (zaznaczając ich specyfikę)? Krainy peryferyjne wyraźnie zdominowały tu Chiny właściwe, których znajdujemy ułomki. A przypomnijmy, że ilustracjom towarzyszą dość obszerne opisy. Obecność jednych tematów, a brak innych tworzy zatem wypaczony obraz.

Ważne miejsce w kulturze chińskiej odgrywa podział przestrzeni na „centrum” (zhong yong), jako jej najważniejszy „nasz” obszar, i „cztery strony” (si fang), którym przypisano mityczne zwierzęta - ,patronów" i odpowiadające im gwiezdne konstelacje (Zielonego Smoka - dla Wschodu, Czerwonego Ptaka - dla Południa, Białego Tygrysa - dla Zachodu i Wojownika Mroku, żółwia oplatanego przez węża - dla Północy; Środkowi odpowiadał Źółty Smok). Podział ten miał przy tym charakter relatywny i zawsze odnosił się do miejsca danego podmiotu. Tylko w odniesieniu do państwa chińskiego stawało się to podziałem administracyjno-etniczno-politycznym na Krainę Środka zamieszkiwaną przez „ludy chińskie” i cztery rodzaje barbarzyńców - wasali wyodrębniane odpowiednio do ich strony świata (Yi - na Wschodzie, Man - na Południu, Rong - na Zachodzie i Di - na Północy). A ponieważ przyjmowano swoistą koncepcję czasoprzestrzeni symbole te odnosily się także do pór roku (wiosnę utożsamiano ze Wschodem, lato z Południem, itd., Środek zaś zazwyczaj pomijano, czasem tylko podawano dlań kilka dni między latem i jesienią). Charakterystyka fragmentów czasoprzestrzeni wiązała się z koncepcją Pięciu Pierwoelementów (wu xing) jako systemu określającego „naturę” każdego przedmiotu oraz zjawiska, jak też ich przemiany. W opisie tego fenomenu kulturowego (s. 110-111) znalazły się jedynie opisy ułamkowe, wiele zbędnych i wątpliwych szczegółów, a nawet podstawowe błędy, zabrakło zaś wielu istotnych elementów pozwalających zrozumieć jego rolę i sens (m.in. odniesień astrologicznych, związków z koncepcjami Yin i Yang oraz z Pięcioma Pierwoelementami, któ- 
re determinują przyporządkowanie określonej barwy każdej ze stron, czy aspektów polityczno-administracyjnych). Miesza się tam zachodnie „kierunki” z chińskimi „stronami świata” mylnie informując czytelnika, że chodzi o to samo.

Autor pisze: ,piątą stronę - środek - dodano później i miała ona znaczenie wyjątkowe, gdyż tam znajdowały się Chiny”. Podział przestrzeni na pięć części znajdujemy już w najstarszych źródłach pisanych, dotyczących epoki pierwszej, historycznie potwierdzonej dynastii Shang (XVI?-XI? w. p.n.e.). Trudno zatem twierdzić, że środek dodano „później”. O mitycznych zwierzętach - uosobieniach 4 stron Autor pisze, że „wyobrażenia te powstały w VII w., i umieszczano je na wewnętrznych ścianach grobowców w Kangso w Sammyo-ri, rejon Nampo (Korea Północna)". Dodaje jeszcze, że występują kontrowersje między koreanistami a sinologami co do ich pochodzenia. Otóż owe cztery zwierzęta stron świata występują w Chinach od epoki Królestw Walczących (475-221 r. p.n.e.), a szczególnie wiele znajdujemy ich $w$ grobowcach epoki Han (206 r. p.n.e. -220 n.e.). Ponadto w 1987 r. w prowincji Henan, miejscowości Xishui powiatu Puyang, odkryto grobowiec neolityczny kultury Yangshao, w którym znajdowały się figury smoka i tygrysa, ułożone z muszli odpowiednio po stronie wschodniej i zachodniej zmarłego. Ich utożsamianie z kierunkami (stronami?) i pierwiastkami Yin i Yang pojawiło się zatem już u samych początków cywilizacji chińskiej, i choćby tylko te dwa zwierzęta występowały w tej funkcji przynajmniej od końca III tysiąclecia p.n.e., a cały system rozwiniętą formę przybrał w ostatnich wiekach p.n.e.

Wspomniane powyżej wykopaliska z Xishui były bardzo głośne, a grobowiec ten - jako jedno z największych odkryć archeologicznych XX w. w Chinach - jest eksponowany w pekińskim Muzeum Historii. Można dodać, że do lat 50. XX w., do czasu nowych odkryć archeologicznych, zakładano, że wyobrażenia 5 stron świata i ich symbole pojawiły się dopiero w II-I w. p.n.e. Wręcz trudno jednak uwierzyć, by wiedza o zdobyczach archeologii chińskiej i ogromnym wzbogaceniu wiedzy o genezie kultury chińskiej w ostatnim półwieczu mogła być obca Autorowi zasiadającemu do pisania takiego dzieła. W średniowiecznej Korei, czy Japonii, znajdziemy oczywiście te symbole w wyniku zapożyczeń z Chin. W tej sytuacji nadzwyczajne eksponowanie w książce jakiegoś grobowca koreańskiego z VII w. jest zupełnie mylące, gdyż grobowców takich, i to o wiele wcześniejszych, znamy z terenu Chin setki. Być może koreański przewodnik opowiadał - w duchu nacjonalistycznym - o „wynalezieniu” tego systemu w Korei, lecz nie należało traktować tego poważnie. W świetle informacji tu przytoczonych jasne jest także, iż nieprawdziwe jest stwierdzenie, jakoby początkowo symbolem Zachodu był jednorożec (qilin), dopiero „później” wyparty przez tygrysa, gdyż tygrysa właśnie spotykamy we wszystkich wyobrażeniach starożytnych, a jednorożec tylko sporadycznie występował w tej roli w średniowieczu.

Autor poświęca tej sprawie dwie strony i cztery ilustracje (nie wiadomo skąd, ze wspomnianego grobowca koreańskiego?) i jest ona istotnie ważna. Autor zdaje się 
przy tym utożsamiać Chiny właśnie ze „środkiem”, co wcale nie jest takie proste (choć nazywa się je potocznie Państwem Środka, także po chińsku - Zhongguo). Sam Autor w ich opisie w Rozdziale I pokazywał - i słusznie - obszerne peryferie zamieszkiwane przez różne nie chińskie ludy. Tradycje państwowości chińskiej są jednak odmiennego rodzaju: zgodnie z nimi Kraina Środka, bezpośrednio zarządzana przez „władcę chińskiego” (czy po prostu „zwierzchniego”), sprawuje zwierzchnictwo nad ,ziemiami wasalnymi”. Tak ukazują formowanie państwa chińskiego mity go dotyczące (kluczową rolę odgrywa w nich Cesarz Żółty, rzekomo panujący w III tysiącleciu p.n.e., który w zaciętych wojnach podporządkował sobie władców czterech stron świata). Podobny obraz rysuje się z najstarszych zapisów historycznych i badań pierwszego, historycznie potwierdzonego państwa dynastii Shang, które istotnie obejmowało centralne ziemie ludu Shang i otaczające je państwa wasalne, dzielone wedle wyidealizowanego schematu na „cztery strony świata" z ich hegemonami odpowiadającymi za utrzymywanie tam porząd$\mathrm{ku}$. Wedle dominujących przez tysiąclecia wyobrażeń dopiero razem tworzyły one „Chiny” w szerokim, państwowym, znaczeniu, czy też ,imperium chińskie” (poza którym Chińczycy z trudem mogą wyobrazić sobie swoje państwo).

Przy opisie państwa chińskiego (s. 58-9) kwestie te jednak nie zostały jasno przedstawione, choć Autor słusznie zwraca uwagę na jego uniwersalistyczną naturę i przytacza tradycyjną nazwę Chin - Tianxia - „Wszystko pod Niebem” (przez niego tłumaczoną jako „Podniebie”, co chyba nie jest pomysłem udanym). Pisze też dość szeroko o „państwach wasalnych”, wprowadzając nawet rozróżnienie na „ziemie zewnętrzne” i ,wewnętrzne” (s. 60). Czytelnika łatwo może jednak zmylić termin ,zagranica”, nazbyt modernistyczny i w przypadku dawnych Chin - mylący. Trzeba też pamiętać, że było wiele kategorii ziem „wasalnych”, zarządzanych przez miejscowych zwierzchników, zatwierdzanych jedynie przez władze chińskie. Istniały one nie tylko poza granicami prowincji chińskich (posiadając rozmaity status), lecz także wewnątrz prowincji, czy nawet powiatów chińskich. Przy obfitości rozmaitych szczegółów, a braku jasności w kwestiach podstawowych, nie jestem pewien, czy z zamieszczonych tu opisów czytelnik zrozumie skomplikowaną naturę i sinocentryczną ideologię Chin, zasadniczo odmienną od nowoczesnych, zachodnich ,państw narodowych”.

Wiele wątpliwości budzi opis prawa chińskiego (s. 75). Stwierdzenie, że prawo tam ,zawsze stało na straży interesów zbiorowości, a nie jednostki”, nie całkiem są słuszne, gdyż znane nam kodeksy przede wszystkim chronią władzę domu cesarskiego i regulują jego funkcjonowanie, podobnie jak podległego mu aparatu biurokratycznego. To stanowiło zazwyczaj główny korpus regulacji kolejnych dynastii. Dopiero pozostała część dotyczyła społeczeństwa, a przede wszystkim podtrzymywania norm moralności konfucjańskiej, propagowanej i chronionej przez cesarza. Dotyczyły więc one w dużej mierze możnych, nie zaś „,maluczkich”, jak błędnie sugeruje Autor. Nie ma tam też zarysowania „zbiorowości” z jej interesa- 
mi, ona pojawia się dopiero w czasach najnowszych. Nasuwa się nieodparcie przypuszczenie, iż Autor nie miał w rękach żadnego z dawnych „kodeksów” chińskich, a korzystał z jakichś popularnych opracowań. Także teza, iż „kolejne kodeksy, przynajmniej od dwóch tysiącleci, zmieniały się tylko w niewielkim stopniu" jest błędna. Najstarszy zachowany kodeks pochodzi z epoki Tang, z VII w. n.e., i dopiero od tego czasu do początków XX w. możemy z pewnością mówić o ciągłości tradycji. Z dawniejszych regulacji znamy jedynie fragmenty. Nawet z nich wiemy też, że w starożytności normy prawne ulegały dużym zmianom.

Pisząc o prawie i kodeksach należałoby chyba wspomnieć o ich specyfice, np. o tym, iż kodeksy były przeznaczone tylko dla funkcjonariuszy państwowych, gdyż miały regulować ich działania, miały zaś pozostawać tajne dla ludu. Można by wspomnieć o odrębnych ,kodeksach norm rytualnych” (li), czy też o organicznym połączeniu władzy administracyjnej i sądowniczej. Należałoby też koniecznie wspomnieć o autonomii sądownictwa i prawodawstwa rodowego, czy wspólnotowego, gdyż to jemu podlegała przede wszystkim ludność i rozstrzyganie jej spraw codziennych (w tym trybie zapadały i wykonywane były nawet wyroki śmierci), podczas gdy lokalni zwierzchnicy administracji zajmowali się występkami najcięższymi, „rangi państwowej”. Nie wiadomo, czemu ma służyć epatowanie czytelnika horrorami opisów kar cielesnych i tortur. Podobnie było przecież także w dawnej Europie. Jeśli już wspominamy o tym, to należałoby napisać także o sporadycznym charakterze wykonywania kary śmierci w dawnych Chinach $w$ ramach jurysdykcji państwowej i o konieczności zatwierdzania takiego wyroku przez organy wyższe, albo nawet przez odległe władze centralne, co wcale nie było czystą formalnością. Drobiazgowość procedur i szczegółowy charakter nadzoru stanowiły bowiem o specyfice systemu chińskiego. Można było też wspomnieć o szczegółowych regulacjach dotyczących nadzoru nad wspomnianą powyżej „sprawiedliwością ludową" (zmierzającego do zapobieżenia samowoli i okrucieństwu, za które sprawcy - sędziowie i wykonawcy - mogli być ukarani przez organy państwowe), o ciekawych próbach walki z korupcją (już w VII w.!), o regulacjach dotyczących bankructwa firm i ochrony interesów wierzycieli, sądzeniu występków między cudzoziemcami według ich własnych norm prawnych, itp. Zamieszczony tu opis razi nieścisłościami i daje bardzo fragmentaryczny obraz prawa oraz sądownictwa w Chinach.

Można nadmienić, że o korupcji Autor pisze oddzielnie, poświęcając jej niewielki, wyodrębniony opis (s. 70), ale znowu niezmiernie powierzchownie, bez wniknięcia w istotę rzeczy. Nie rozdziela „korupcji kryminalnej” od zwyczajowego wyrażania wdzięczności i nie ukazuje opłat dla funkcjonariuszy państwowych o charakterze systemowym (co było związane z zasadą „opłaty interesanta za usługę" i sposobem finansowania urzędów państwowych; dopiero domaganie się opłat „nadmiernych” uznawano za patologiczne). Stanowczo zbyt często spo- 
tykamy się tu z opisami bardzo płytkimi, stereotypowymi, ograniczonymi do naiwnych „wyobrażeń obiegowych”.

Rozmaite kłopoty ma zresztą Autor nie tylko z kwestiami kultury tradycyjnej, ale i z historią XX w. Biograficzny szkic o Sun Yat-senie - Ojcu Republiki Chińskiej (s. 297) bardzo rozczarowuje. Co najmniej nieścisła jest informacja, iż dopiero po „powstaniu bokserów” Chiny „stały się półkolonią Zachodu”. Ulegały tej degradacji już w XIX w., a powstanie było buntem ludowym przeciwko zniewoleniu, ponadto zaś aktywną rolę w podporządkowywaniu Chin odgrywała też Japonia. Nie tylko więc o ucisk Zachodu chodziło. Autor wyraźnie przesadza też z „powszechnym znienawidzeniem" urzędników mandżurskich: tak pisywali rewolucyjni działacze z emigracji, ale w samych Chinach postawy takie były zupełnie marginesowe, dlatego bunty wszczynane z zagranicy załamywały się w zarodku. Nazwy podstawowych koncepcji Suna zostały źle przetłumaczone. Według Autora jego Trzy Zasady Ludowe to: nacjonalizm, „prawa ludu” i „byt ludu”. W istocie chodziło zaś o „patriotyzm” ( przy anglosaskim pojmowaniu narodu jako „ludu państwa” bez względu na podziały etniczne), ,władzę ludu” (minquanzhuyi) i „dobrobyt ludu" (minshengzhuyi). Stwierdzenie mówiące, jak to rzekomo szerokie kręgi społeczne organizowały się w stworzonej przez niego (w 1905 r. w Tokio!) Chińskiej Lidze Związkowej - grzeszy nadmiernym ,rewolucyjnym optymizmem”: była to bowiem niewielka organizacja kadrowych rewolucjonistów - intelektualistów działająca głównie na emigracji, o szerszym udziale chłopów i robotników w kraju mogli oni tylko pomarzyć. Za późno jest datowane utworzenie Partii Narodowej - Guomindang: założono ją nie ,po roku” od rezygnacji Suna w 1912 r., lecz już po kilku miesiącach, tak by mogła ona wziąć udział w pierwszych wyborach pod koniec tego samego roku (odniosła w nich duży sukces). Choć chodzi pozornie o kilka miesięcy, ale był to okres rewolucyjnych przemian, kiedy czas inaczej biegnie. Tworzenie tej partii po wyborach nie miałoby po prostu sensu. Sun abdykował nie „dla świętego spokoju”, lecz było to częścią politycznej ugody: bez tego armia kierowana przez Yuan Shikaia, stary establishment i obce mocarstwa, czyli główne siły posiadające realną władzę nie zaakceptowałyby Republiki proklamowanej przez ugrupowania radykalne. Pisanie, że Sun ponownie stanął na czele państwa w 1921 r. - to już zupełne fantasmagorie. Odnosi się to chyba do drugiej, mało udanej próby proklamowania przezeń Rządu Narodowego w Kantonie, którego wpływy nie wiele sięgały poza samo miasto, ostro zwalczanego nawet w tej południowej metropolii. Chiny pogrążone były wówczas w chaosie, a marionetkowe władze - choć międzynarodowo uznane, jak rząd i prezydent - miały siedzibę w Pekinie. Sun jedynie zabiegał wtedy o zjednoczenie kraju i odbudowę państwa, a osiągnął to dopiero jego dziedzic Czang Kai-szek w 1928 r., po zakończeniu serii wojen domowych.

Często znajdujemy rozmaite nieścisłości, albo też informacje bardzo zubożone, czy nawet wypaczone przez niewłaściwy kontekst. Przykładem tego ostatnie- 
go może być np. informacja o „magicznych znaczeniach” dni roku, określających, co można było robić danego dnia (s. 94), a dokładniej, co danego dnia można było robić pomyślnie. Pomijając już mętność samego opisu, następuje on po - również dość dyletanckim - opisie trygramów, heksagramów i Księgi przemian, co sugerowałoby związek tych wierzeń z ową sławną księgą. W istocie zaś to odrębny kompleks wierzeń i praktyk związanych z czasem, choć wykorzystywano w nich elementy nauk magicznych, w tym i trygramy, Pięć Pierwoelementów, itd. Problemowi pojmowania czasu w sposób nieciągły, odmiennej natury poszczególnych jego pór zmieniających się w ramach rozmaitych cykli, i specyficznych praktyk magicznych z tym związanych - należało poświęcić po prostu odrębny opis.

Wtedy też ukazałby się ich związek, czy raczej pokrewieństwo koncepcyjne, z Księga przemian, jako narzędziem „,mistycznej prognostyki” raczej niż dziełem wróżebnym. Pogląd, iż jest ona takim dziełem należy wprawdzie do tez obiegowych, ale od pracy poświęconej kulturze chińskiej czytelnik ma prawo oczekiwać profesjonalnych i głębszych objaśnień. Gdyby chociaż raz Autor skorzystał z tej sławnej księgi zrozumiałby zaraz jak bardzo uproszczone, by nie powiedzieć naiwne, są jego tezy o jej wróżbiarskim charakterze (potwierdzone zaraz wzmiankami o innych praktykach wróżbiarskich). Wspomnijmy jeszcze, że Księga może umożliwiać kontakt z dao, czy „,rozumem wszechświata”, dawać przeżycia mistyczne, czy służyć specyficznej „głębokiej auto-psychoanalizie intuicyjnej”, a bywa stosowana nawet przez wybitnych chińskich intelektualistów, również współcześnie. Jej ogromne znaczenie w kulturze chińskiej zostało jaskrawo niedocenione. Wspomnijmy jeszcze, że pojawiająca się tu teza o wyraźnym materializmie filozofii chińskiej - to jakieś pogłosy dawnych stalinowsko-maoistycznych ujęć. Ślady ich tu i ówdzie pojawiają się, np. w użyciu kategorii „burżuazyjny”, odwołaniach do robotników i chłopów, itd. (patrz np. wspomniany powyżej opis poświęcony Sun Yat-senowi). Choć dominowały one w dawnej literaturze radzieckiej, a do dziś występują w publikacjach krajów azjatyckich przyjmujących poprzednio komunizm - nie należy zbyt łatwo ulegać takim wpływom.

Jako przykład braku precyzji zacytujmy informacje odnoszące się do języka (s. 37). ,język chiński należy do rodziny chińsko-tybetańskiej i wyróżnia się w nim aż osiem wielkich odmian regionalnych, zwanych dialektami lub nawet językami...” Dalej mówi się o różnicach między językami „nawet z jednej odmiany”. Po pierwsze informacja o tej rodzinie jest chyba ujęciem nieco przestarzałym. Po drugie, cóż za mieszanie trzech kategorii: „odmiana”, ,język”, „dialekt”, w których znowu są ,języki”! Jest dobra praca J. M. Künstlera, Języki chińskie (Dialog, 2000) i wypadało z niej po prostu skorzystać! Uproszczeń hieroglifów w XX w. były najwyżej setki, nie „tysiące” (s. 40); znakowi istotnie odpowiada sylaba, ale już nie „wyraz jedno- lub więcej “sylabowy”" (s. 41). Tak może być w języku japońskim, ale nie chińskim! Stwierdzenie „pismo chińskie nie tworzy alfabetu” - 
jest porażające. Jeśli pismo to ma charakter ideograficzny, a nie służy zapisowi strony fonetycznej, to trudno mówić tam o alfabecie.

Konfucjusza nie podniesiono do rangi bóstwa pod koniec monarchii i nie traktuje się go tak na Tajwanie (patrz s. 95), a w początkach XX w. był jedynie projekt przekształcenia konfucjanizmu w oficjalną religię Chin (na podobieństwo shintoizmu w Japonii), ale nigdy nie podjęto takiej decyzji i nie mogłaby ona liczyć na szerszą akceptację. Taoizm nie zalecał ani „żywienia się śliną oraz powietrzem”, ani „orgii seksualnych”, wbrew temu, co pisze Autor (s. 96). W pierwszym przypadku chodziło o wzmacnianie swej specyficznej energii duchowej qi przez rozmaite fluidy, w drugim zaś o pobudzenie erotyczne i wchłanianie żeńskiego fluidu yin przez mężczyznę dla wzmożenia energii życiowych i przedłużania życia. Osiągniecie przezeń poziomu wytrysku i rozkoszy niweczyłoby zaś cały zabieg! To po prostu jakieś zupełne nieporozumienie i próba epatowania czytelnika prymitywnymi tezami, dla jakich w poważnej pracy nie powinno mieć miejsca. Takie nonsensy mogą sobie co najwyżej wypisywać autorzy tandetnych książek pisanych jako bestsellery dla publiki amerykańskiej.

Autor błędnie utożsamia system hukou wprowadzony w ChRL z dawnym systemem baojia - łączenia rodzin w systemie dziesiątek, setek i tysięcy (s. 77). W istocie obydwa mają podobnie antyczny rodowód, ale ten pierwszy służył utrwalaniu podziałów stanowych poprzez swoiste przypisanie rodziny do miejsca zamieszkania, zaś drugi - nadzorowi nad ludnością i zwalczaniu przestępczości. Błędna jest informacja, że duszę hun człowiek otrzymywał przy urodzeniu (s. 86), gdyż tę ,duszę moralno-intelektualną” posiadali nie wszyscy, a trzeba ją było dopiero w sobie wytworzyć. I tylko ona mogła trwać przez pokolenia. Natomiast każdy miał animalną duszę po, która jednak ulegała rozkładowi po śmierci.

Takich nieścisłości, czy błędów jest wiele i stanowią one niestety przysłowiową łyżkę dziegciu w beczce miodu. $\mathrm{Z}$ takiej niedbałości w przygotowaniu dzieła wynika bowiem konieczność pracochłonnego i trudnego sprawdzania, czy w danym przypadku informacje podawane przez Autora są ścisłe. Nawet jeśli można je podważać tylko w $10 \%$, jest to rujnujące dla wiarygodności książki mającej służyć jako wiarygodne źródło informacji o Chinach. Tym bardziej przykro, iż najwięcej ich dostrzec można we wspomnianych dodatkowych opisach - swoistych „mini-monografiach tematycznych". Rażą też czasem spotykane potworki językowe. Czytamy, np., że hieroglify zawierają element kluczowy „zwany też radykałem” (s. 41). Jest to kalka $\mathrm{z}$ angielskiego (radicals), ale termin ten ma po polsku zupełnie inne znaczenie: radykałów miewamy w sejmie, albo poza nim, nie zaś w słownikach! Klasztorem taoistycznym zarządzać też powinien chyba następca (czy potomek) Niebiańskiego Mistrza nie zaś tajemniczy „descendent” (s. 97), co znowu jest językowa kalką. Trzeba jednak docenić, że terminy chińskie są poprawnie transkrybowane w systemie pinyin. Zdziwienie budzić może również nader wybiórcze odwoływanie się do polskich publikacji o Chinach: albo Autor słabo zna tę niezbyt 
przecież pokaźną literaturę, albo też stosuje jakieś zupełnie poza merytoryczne kryteria korzystania z niej, co w każdym przypadku podważa wartość pracy.

Nasuwać się może przypuszczenie, że po prostu Autor nie dopracował tej pracy redakcyjnie, nie przeczytał raz jeszcze tego, co napisał, nie zechciał sięgnąć do specjalistycznych opracowań, a polegał na swej pamięci, niestety ułomnej, i stąd pojawia się w niej tyle słabości. Jeśli tak było, to można wyrazić życzenie, by za jakiś czas pojawiło się jej drugie, dopracowane już wydanie.

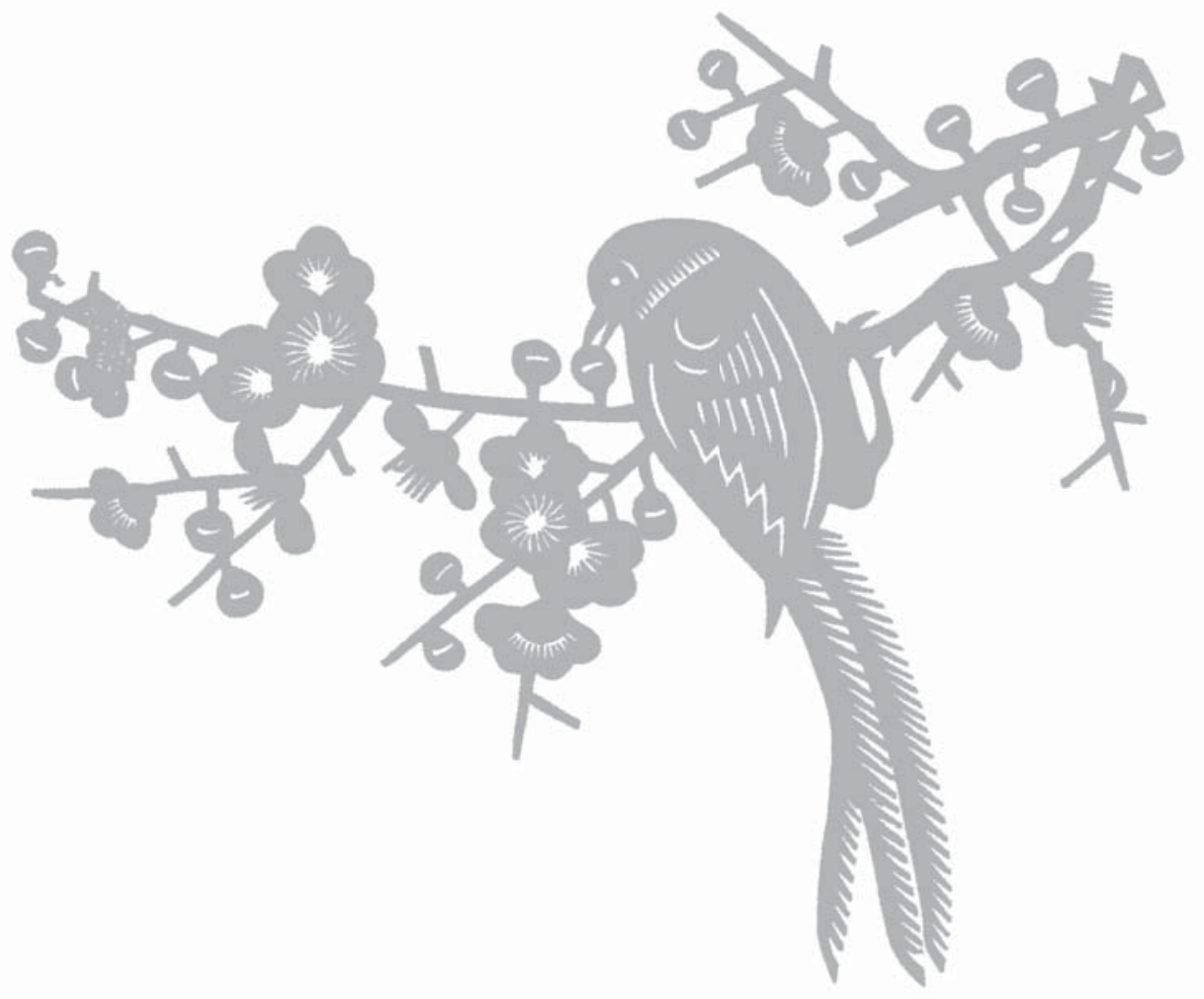

